УДК 504.064.47

03.02.08 Экология

СОВРЕМЕННЫЕ СПОСОБЫ ОБЕЗВРЕЖИВАНИЯ И УТИЛИЗАЦИИ НЕФТЕСОДЕРЖАЩИХ ОТХОДОВ ДЛЯ ЛИКВИДАЦИИ ЗАГРЯЗНЕНИЯ ОКРУЖАЮЩЕЙ СРЕДЫ

Литвинова Татьяна Андреевна канд. техн. наук, доцент SPIN-код 3028-9469

Кубанский государственный технологический университет, Краснодар, Россия

В статье рассмотрена проблема ликвидации загрязнения окружающей среды нефтесодержащими отходами и предложены современные направления совершенствования технологий их обезвреживания и утилизации. Приведена сравнительная характеристика сущности, достоинств и недостатков, эффективности способов утилизации нефтеотходов. Выделены основные технологии утилизации нефтешламов различного происхождения, с учетом особенностей их состава и свойств. Представлены результаты патентного поиска по данному направлению для обеспечения высокого технического уровня новых разработок. Охарактеризованы разработанные технологии для обезвреживания и утилизации нефтесодержащих отходов с получением экологически безопасных продуктов утилизации - органоминеральных добавок, пригодных к использованию в качестве вторичных материальных ресурсов

КЛючевЫе слова: НЕФТЕСОДЕРЖАЩИЕ ОТХОДЫ, УТИЛИЗАЦИЯ, ЛИКВИДАЦИЯ ЗАГРЯЗНЕНИЯ ОКРУЖАЮЩЕЙ СРЕДЫ, ЭКОЛОГИЧЕСКАЯ БЕЗОПАСНОСТЬ, НАИЛУЧШИЕ ДОСТУПНЫЕ ТЕХНОЛОГИИ
UDC 504.064.47

Ecology

\section{MODERN WAYS OF OIL-CONTAMINATED \\ WASTE UTILIZATION FOR THE ELIMINATION OF POLLUTION}

\author{
Litvinova Tatiana Andreevna \\ Cand.Tech.Sci., Assistant Professor \\ RSCI SPIN-code 3028-9469 \\ Kuban State Technological University, Krasnodar, \\ Russia
}

\begin{abstract}
The article deals with the problem of eliminating environmental pollution by oil-contaminated waste. It's suggested modern ways of improving technologies for oily waste utilization. The comparative characteristic of the essence, advantages and disadvantages, effectiveness of ways of waste recycling is described. The basic utilization technologies of oil sludge of various origins are emphasized taking into account the aspects of their composition and properties. It's represented the results of a patent search in this area to ensure a high level of new developments. It's characterized the developed technologies for utilization and recycling of oily waste to produce environmentally products of utilization - organic and mineral additives which are suitable for use as secondary material resources
\end{abstract}

Keywords: OIL-CONTAMINATED WASTE, UTILIZATION, ELIMINATION OF POLLUTION, ECOLOGICAL SAFETY, BEST AVAILABLE TECHNIQUES

Doi: 10.21515/1990-4665-123-062

Проблема негативного влияния на биосферу отходов, образующихся при добыче, транспортировке, переработке, хранении углеводородного сырья, решается недостаточно. В результате миграции вредных веществ происходит загрязнение окружающей среды. Сложный компонентный состав отходов нефтегазовой отрасли затрудняет выбор способа их переработки. В связи с этим актуальным и востребованным является разработка эффективных способов обезвреживания отходов нефтегазовой 
отрасли и наилучших доступных технологий их утилизации для ликвидации загрязнения воздуха, водоемов, почвы отходами 2-3 класса опасности и реабилитации окружающей среды.

Для правильной организации деятельности по переработке, обезвреживанию и утилизации отходов необходимо учитывать состав, количество и свойства отходов, а также факторы, влияющие на их изменения. Выбор способа обработки нефтешламов зависит от их фазового состава: количества содержащихся нефтепродуктов, воды и механических примесей. Все известные технологии по методам переработки можно разделить на следующие группы:

- термические - сжигание в открытых амбарах, печах различных типов, получение битуминозных остатков [1-4];

- механические - перемешивание и физическое разделение нефтешламов гравитационным отстаиванием, в центробежном поле, фильтрованием [5-6];

- химические - экстрагирование с помощью растворителей, отверждение с применением добавок, обработка гидрофобными реагентами на основе негашеной извести или других материалов [7-14];

- физико-химические - применение специально подобранных реагентов, изменяющих физико-химические свойства, с последующей обработкой на специальном оборудовании [15];

- биологические - микробиологическое разложение в почве непосредственно в местах хранения, биотермическое разложение с применением специальных углеводородокисляющих бактерий [16-17].

Сравнительная характеристика способов обезвреживания и утилизации отходов представлена таблице 1. Зачастую только механические или физико-химические методы не могут дать эффективного разделения, а, следовательно, обезвреживания из-за высокой стабильности 
шлама. При этом, чем дольше хранится шлам и чем сложнее пути его образования, перекачки и транспортировки, тем выше стабильность.

\section{ТабЛИЦа 1 - СРАВНИТЕЛЬНАЯ ХАРАКТЕРИСТИКА МЕТОДОВ УТИЛИЗАЦИИ НЕФТЕШЛАМОВ}

\begin{tabular}{|c|c|c|c|}
\hline Метод & Разновидность метода & Преимущества & Недостатки \\
\hline 1 & 2 & 3 & 4 \\
\hline \multirow[t]{3}{*}{ Термический } & $\begin{array}{l}\text { Сжигание в печах } \\
\text { различных } \\
\text { конструкций } \\
\end{array}$ & $\begin{array}{l}\text { Высокая эффективность } \\
\text { обезвреживания, применимо для } \\
\text { многих видов отходов }\end{array}$ & $\begin{array}{l}\text { Большие затраты по очистке } \\
\text { и нейтрализации дымовых } \\
\text { газов }\end{array}$ \\
\hline & Пиролиз & $\begin{array}{l}\text { Высокая степень разложения, } \\
\text { возможность использования } \\
\text { продуктов разложения }\end{array}$ & $\begin{array}{l}\text { Высокие материальные и } \\
\text { энергетические затраты }\end{array}$ \\
\hline & $\begin{array}{l}\text { Электроогневое } \\
\text { сжигания }\end{array}$ & $\begin{array}{l}\text { Создаются практически } \\
\text { идеальные условия горения } \\
\text { пламени сжигаемых отходов, } \\
\text { высокая степень очистки } \\
\text { дымовых газов }\end{array}$ & $\begin{array}{l}\text { Высокие материальные и } \\
\text { энергетические затраты }\end{array}$ \\
\hline \multirow[t]{5}{*}{ Физический } & $\begin{array}{l}\text { Гравитационное } \\
\text { отстаивание }\end{array}$ & $\begin{array}{l}\text { Не требует больших капитальных } \\
\text { и эксплуатационных затрат }\end{array}$ & $\begin{array}{l}\text { Низкая эффективность } \\
\text { разделения }\end{array}$ \\
\hline & $\begin{array}{l}\text { Разделение в } \\
\text { центробежном поле }\end{array}$ & $\begin{array}{l}\text { Возможность интенсификации } \\
\text { процесса }\end{array}$ & $\begin{array}{l}\text { Требуется специальное } \\
\text { оборудование } \\
\text { (гидроциклоны, сепараторы, } \\
\text { центрифуги), дороговизна } \\
\text { оборудования }\end{array}$ \\
\hline & $\begin{array}{l}\text { Разделение } \\
\text { фильтрованием }\end{array}$ & $\begin{array}{l}\text { Сравнительно низкие затраты, } \\
\text { высокая степень надежности, } \\
\text { высокое качество целевых } \\
\text { продуктов, менее } \\
\text { требователен к качеству сырья }\end{array}$ & $\begin{array}{l}\text { Необходимость смены и } \\
\text { регенерации } \\
\text { фильтрующихся } \\
\text { материалов, образование } \\
\text { неутилизируемых остатков }\end{array}$ \\
\hline & $\begin{array}{l}\text { Кавитационное } \\
\text { обезвоживание }\end{array}$ & $\begin{array}{l}\text { Экономически эффективный, } \\
\text { снижение содержания } \\
\text { остаточной воды в 2-3 раза }\end{array}$ & $\begin{array}{l}\text { Необходимость } \\
\text { поддержания перепада } \\
\text { давлений на аппарате не } \\
\text { ниже определенных } \\
\text { значений }\end{array}$ \\
\hline & $\begin{array}{l}\text { Виброкавитационное } \\
\text { измельчение }\end{array}$ & $\begin{array}{l}\text { Низкие энергозатраты, высокая } \\
\text { степень эффективности, } \\
\text { возможность утилизации разных } \\
\text { по составу нефтешламов, в том } \\
\text { числе и донных }\end{array}$ & Затраты на оборудование \\
\hline Химический & $\begin{array}{l}\text { Химическое } \\
\text { капсулирование } \\
\text { загрязняющих веществ } \\
\text { гидрофобными } \\
\text { реагентами на основе } \\
\text { оксида кальция }\end{array}$ & $\begin{array}{l}\text { Простота технологии, быстрота } \\
\text { утилизации, высокая } \\
\text { эффективность процесса, } \\
\text { возможность использования } \\
\text { продуктов утилизации в качестве } \\
\text { вторичных материальных } \\
\text { ресурсов }\end{array}$ & $\begin{array}{l}\text { Высокий расход реагентов } \\
\text { на тонну нефтешлама, } \\
\text { стоимость реагентов }\end{array}$ \\
\hline $\begin{array}{l}\text { Физико- } \\
\text { химический }\end{array}$ & $\begin{array}{l}\text { Применение } \\
\text { специально } \\
\text { подобранных ПАВ } \\
\text { (деэмульгаторов, } \\
\text { диспергаторов) }\end{array}$ & $\begin{array}{l}\text { Возможность интенсификации } \\
\text { процессов при введении } \\
\text { небольших количеств добавок }\end{array}$ & $\begin{array}{l}\text { Высокая стоимость } \\
\text { реагентов, требуется } \\
\text { специальное дозирующее и } \\
\text { перемешивающее } \\
\text { оборудование, образуются } \\
\text { неутилизируемые остатки }\end{array}$ \\
\hline
\end{tabular}


Окончание таблицы 1

\begin{tabular}{|c|c|c|c|}
\hline 1 & 2 & 3 & 4 \\
\hline & $\begin{array}{l}\text { Виброкавитационная } \\
\text { экстракция (промыв с } \\
\text { ультразвуком) }\end{array}$ & $\begin{array}{l}\text { Выход товарной нефти, } \\
\text { возможность утилизации грунтов }\end{array}$ & $\begin{array}{l}\text { Высокие эксплуатационные } \\
\text { расходы, необходимость } \\
\text { использования реагентов }\end{array}$ \\
\hline \multirow[t]{3}{*}{ Биологический } & $\begin{array}{l}\text { Биоразложение с } \\
\text { применением } \\
\text { специальных } \\
\text { штаммов бактерий }\end{array}$ & $\begin{array}{l}\text { Возможность интенсификации } \\
\text { процесса, требуются } \\
\text { незначительные капитальные и } \\
\text { энергетические затраты }\end{array}$ & $\begin{array}{l}\text { Требуется значительная } \\
\text { подготовка земельных } \\
\text { участков и специальное } \\
\text { оборудование }\end{array}$ \\
\hline & Биоремедиация & $\begin{array}{l}\text { Восстановление почвенного } \\
\text { покрова }\end{array}$ & $\begin{array}{l}\text { Необходимость организации } \\
\text { полигонов, строгая } \\
\text { зависимость от } \\
\text { температурных условий }\end{array}$ \\
\hline & $\begin{array}{l}\text { Засеивание } \\
\text { растениями }\end{array}$ & $\begin{array}{l}\text { Восстановление почвенного } \\
\text { покрова }\end{array}$ & $\begin{array}{l}\text { Длительность процесса, } \\
\text { требования к природным } \\
\text { условиям }\end{array}$ \\
\hline
\end{tabular}

В зависимости от технических возможностей предприятия, характеристик нефтесодержащих шламов и экологических требований для их утилизации может использоваться один из вышеперечисленных методов или их сочетание. Комплексные схемы переработки комбинируют отстаивание, флотацию, дегазацию, кондиционирование, осушку, обработку коагулянтами и флокулянтами, уплотнение, разделение, биоразложение [18-19].

Исходя из анализа сущности, достоинств и недостатков методов переработки нефтешламов (табл. 1) и особенностей состава и свойств отходов, можно выделить основные технологии утилизации нефтеотходов различного происхождения. Нефтешламы, собранные в процессе зачистки резервуаров, традиционно подвергаются разделению на нефтепродукт, воду и твердые механические примеси. Извлеченные из шламов нефтепродукты используют по прямому назначению. Для фазового разделения жидковязких нефтешламов используют механический и химический методы. Для более глубокой очистки нефтепродуктов применяют комплексную технологию. Несмотря на большое разнообразие технических приемов механического разделения технология сложна и экономически не выгодна, поскольку затраты не регенерацию нефтепродуктов несопоставимы с планируемым эффектом использования 
жидких горючих (бензина, масла и т.д.). Наиболее простым способом утилизации жидковязких нефтешламов с высоким содержанием органики является прямое, без фазового разделения использование их в смесях с торфом, угольной пылью, опилками или другими дешевыми горючими веществами и отходами в качестве брикетированного котельного топлива. Большинство резервуарных нефтешламов подлежат также прямой утилизации в процессах изготовления дорожных и строительных материалов в качестве сырья.

Сбор и удаление донных нефтешламов с содержанием механических примесей до $70 \%$ осложняется большими геометрическими размерами шламонакопителей и отсутствием удобных подходов к ним. Данные отходы обрабатывают термическими или химическими способами. Наиболее перспективными являются последние, так как продукт утилизации возможно использовать как вторичный материальный ресурс.

Химический метод предполагает капсулирование компонентов нефтеотходов в известковые оболочки. Широкое распространение среди реагентов в практике утилизации нефтешламов получила окись кальция или негашеная известь, действие которой обусловлено ее способностью вступать в экзотермическую реакцию с водой с образованием гашеной извести с развитой удельной поверхностью. Особенность этой реакции заключается в том, что она идет со значительной задержкой, ускоряясь при разогреве смеси. В итоге получают мелкодисперсный порошок, проявляющий инертные свойства по отношению к воде и почве. Дополнительно к негашеной извести добавляют ПАВ из класса жирных и сульфокислот, а также других высокомолекулярных природных и синтетических веществ. При смешении нефтешлама с этими компонентами в пропорции от 1:1 до 1:10 происходит адсорбция отходов на поверхности гидроокиси кальция. В результате получают сухой гидрофобный порошок [7-11]. Изменение состава реагентов за счет введения 
кремнеземсодержащих добавок способствует получению более экологически безопасных продуктов [12-14].

В результате патентного поиска по технологиям утилизации нефтесодержащих отходов химическим способом выявлено, что большее количество патентов относится к реагентным или комбинированным методам с применением оксида кальция и получением продуктов утилизации, представляющих собой вторичные материальные ресурсы, пригодные к использованию в различных отраслях промышленности.

Анализ технических решений отобранных патентных документов по способам утилизации нефтесодержащих отходов реагентным методом и составам реагентов показал следующие решаемые ими задачи и достигаемые технические результаты:

- упрощение состава обезвреживающего реагента, обеспечение экологической безопасности обезвреженных отходов, снижение водопоглощения утилизированных отходов, упрощение технологических операций по обезвреживанию углеводородных отходов (патент РФ на изобретение №2187466). В качестве обезвреживающего компонента используют оксид кальция и магния. Смешение проводят при следующих соотношениях компонентов, мас.\%: оксид кальция - 10-40; оксид магния 3-5; нефтяной шлам - до 100;

- создания дешевого сорбента, имеющего высокую степень очистки от нефтемаслоотходов (патент РФ на изобретение № 2160758). Сорбент получают путем введения в порошкообразную негашеную известь технического животного жира с последующим перемешиванием;

- создание дешевого сорбента, состоящего из доступных компонентов, которые, хорошо перемешиваясь с негашеной известью, способны обезвреживать и утилизировать токсичные нефтемаслоотходы, содержащие ионы тяжелых металлов, легкие фракции углеводородов, в том числе серосодержащие и парафино-смолистые отложения (патент РФ 
на изобретение №2281157). Сорбент состоит из негашеной извести, активированного угля и поверхностно-активного вещества в составе костной муки при следующем соотношении компонентов, мас.\%: костная мука 0,4-3,0; активированный уголь до 10,0; негашеная известь остальное;

- обезвреживание нефтеотходов с получением продукта, инертного к воде и почве (патент РФ на изобретение №2317259). Способ включает переработку нефтеотходов путем их сепарации с выделением твердого нефтесодержащего отхода, который смешивают с негашеной известью в соотношении 1:1 с добавкой модификатора, содержащего соли фосфорной кислоты $1-10 \%$ от количества негашеной извести, и тщательно перемешивают до получения однородной массы;

- получение изолирующего материала, применяемого при захоронении твердых бытовых отходов (ТБО) и токсичных промышленных отходов 3- и 4-го класса опасности, а также снижение обводненности, коэффициента фильтрации и пожароопасности (патент РФ на изобретение №2274502). Нефтешлам смешивают со шламом химиводоочистки или с обожженной размолотой товарной известью в соотношении 1:1-2 соответственно, затем послойно промораживают и оттаивают в естественных условиях. В обезвоженную смесь добавляют частично глину или буровой шлам в соотношении 1:0,5;

- сокращение общей продолжительности биотермической обработки органосодержащих отходов с 1-3 месяцев до 18-30 суток, что позволяет использовать полученный рекультивационный материал для заполнения отработанных карьеров, в планировочных работах, a также для технического экранирования накопителей промышленных отходов на стадии их ликвидации или консервации (патент РФ на изобретение №2450873). Указанный технический результат достигается тем, что в способе переработки нефтешламов и очистки замазученных грунтов в 
качестве щелочного реагента используют шламы химводоочистки теплоэлектроцентралей;

- повышение водостойкости продукта утилизации, прочности за счет хорошего сцепления между вяжущим нефтешламом и минеральными компонентами (патент РФ на изобретение № 2238250). Способ включает смешение нефтесодержащего отхода с минеральными компонентами в соотношении 1: 5;

- переработку любого нефтесодержащего шлама не зависимо от его природы и вязкости (нефти, масла, мазута, гудрона и т.д.), срока и места его захоронения, содержания влаги в шламе (патент РФ на изобретение №2266258). Нефтешлам предварительно обрабатывают до получения равномерной по составу и вязкости смеси путем его перемешивания, разогрева и введения органического разжижителя, загрузку рабочего агента осуществляют двумя равными порциями, причем первую - до загрузки обработанного нефтесодержащего шлама, а вторую одновременно с ним, затем вводят жидкость, нагретую до $60-70^{\circ} \mathrm{C}$. Перемешивание компонентов ведут в смесителе при скорости вращения 100-150 об./мин в течение 15-20 мин;

- снижение класса опасности отходов, а также защита окружающей среды от пыли, легких фракций углеводородов и сероорганики в процессе обезвреживания (патент РФ на изобретение №2305116). Способ обезвреживания отходов включает подачу в смеситель негашеной извести и модификатора- технического жира, вес которого составляет до 5\% от массы негашеной извести. Далее проводят распределение их по всей длине смесителя, подачу в смеситель отходов при содержании жидких и/или пастообразных углеводородов менее $50 \%$ от общего веса отходов. Соотношение между отходами и негашеной извести применяют в пределах от 1:1 до 1:2. Образовавшуюся пылегазовоздушную смесь направляют из смесителя в блок очистки; 
- улучшение свойств продукта утилизации за счет образования карбонатов кальция (патент РФ на изобретение №2354670). Рабочий агент получают путем смешения негашеной извести, адсорбента (продукта пиролиза изношенных автомобильных покрышек при температуре от 850 до $1100^{\circ} \mathrm{C}$ ), и триглицерида высших жирных карбоновых кислот (животный технический жир) при следующем соотношении компонентов, мас.\%: животный технический жир - 1-3; адсорбент - 18-22; негашеная известь - остальное. Способ обезвреживания заключается в интенсивном перемешивании рабочего агента с нефтесодержащими отходами с добавлением воды в количестве, необходимом для полного гашения извести, с учетом воды, содержащейся в нефтеотходе. Продукт утилизации обрабатывают углекислым газом в течение 10-15 минут и выдерживают в герметизированных условиях в течение от 18 до 30 часов;

- улучшение свойств продукта утилизации за счет образования силикатов кальция (патенты РФ на изобретение №2359982, 2395466). Способ утилизации нефтесодержащих отходов по патенту РФ №2359982 включает получение рабочего агента путем смешения негашеной извести, триглицерида высших жирных карбоновых кислот (животный технический жир) и адсорбента в виде термически обработанной рисовой лузги при следующем соотношении компонентов, мас.\%: триглицерид высших жирных карбоновых кислот 1-3, адсорбент 18-22, негашеная известь остальное. Далее осуществляют интенсивное перемешивание полученного рабочего агента с нефтеотходами с добавлением необходимого количества воды. Способ обезвреживания нефтесодержащих отходов по патенту РФ №2395466 включает получение обезвреживающей композиции и смешение eе c нефтесодержащим шламом в соотношении $(1,5-2) \div 1$. Обезвреживающая композиция состоит из предварительно измельченных негашеной извести (оксида кальция) в количестве $70-75 \%$ по массе и отработанного силикагеля - отхода газовой промышленности на стадии 
осушки природного газа, в количестве $25-30 \%$ по массе. К нефтесодержащему шламу добавляют требуемое для полного гашения извести количество воды, определенное с учетом имеющейся в шламе и водопоглощаемости отработанного силикагеля. Продукт обезвреживания нефтесодержащего шлама выдерживают в течение 3 суток;

- капсулирование компонентов отходов с одновременным отверждением (патент РФ на изобретение № 2413835). В способе утилизации методом реагентного капсулирования в качестве консолидирующего материала используют смесь реагента капсулирования, многотоннажного отхода цементной промышленности в виде цементной пыли при следующем соотношении компонентов, мас.\%: реагент капсулирования - 20-30, цементная пыль 15-30, нефтеотход - остальное;

- получение при контролируемом расходе реагента оксида кальция экологически безопасной органоминеральной добавки, пригодной к использованию в качестве эффективной комплексной добавки в строительные материалы, в частности, в керамзит, для повышения их качества, а также снижение щелочности водной вытяжки и эмиссии загрязняющих веществ (патент РФ на изобретение № 2548441). Способ получения органоминеральной добавки заключается в перемешивании нефтесодержащего шлама с предварительно измельченными до мелкодисперсного состояния негашеной известью и отработанным силикагелем с последующим введением воды, а полученную органоминеральную добавку выдерживают до окончания процесса образования кальцийсиликатной структуры. При этом первоначально определяют количество нефтепродуктов в нефтесодержащем шламе стандартными методами, исходя из которого, рассчитывают необходимое количество негашеной извести. На основании полученных данных рассчитывают необходимое количество отработанного силикагеля. 
Таким образом, в результате проведенных патентных исследований выявлены тенденции развития технологий в области обращения с отходами. Улучшение реагентного способа обезвреживания нефте шламов связано с совершенствованием состава рабочих агентов, обезвреживающих композиций путем ввода модификаторов для обеспечения гидрофобности продукта обезвреживания, сорбентов для поглощения тяжелых металлов и других экотоксикантов, содержащихся в отходах. Кроме того, перспективным является введение кремнеземсодержащих сорбентов для повышения экологической безопасности получаемых продуктов.

На кафедре технологии нефти и газ разработаны и запатентованы технологии утилизации нефтесодержащих отходов путем введения поглощающих добавок на основе промышленных отходов, в том числе нефтегазовой отрасли (отработанные кремнеземсодержащие сорбенты: силикагели, ОДМ-2Ф, диатомиты, углеродсодержащие сорбенты, продукты пиролиза изношенных автомобильных шин, термически обработанной рисовой шелухи) [12-14, 20-30]. Спроектированы технологические линии по обезвреживанию нефтешламов [27-29], предусматривающие соблюдение экологических требований к безопасности процесса. При совершенствовании технологий реагентного капсулирования реализуется инновационный подход, основанный на применении принципов наилучших доступных технологий [31-33] для обеспечения комплексной защиты окружающей среды, рационального природопользования, ресурсосбережения и возврата отходов в ресурсный цикл.

\section{Список литературы}

1 Черняховский Э. Р., Шкидченко А. Н., Юматова О. А., Чушкина 3. Ю. Применение различных технологий при ликвидации последствий аварийных разливов нефти, нефтепродуктов и продуктов переработки нефтесодержащих отходов // Защита населения и территории от чрезвычайных ситуаций. 2003. № 2. С.12-13.

2 Дудышев В.Д. Утилизация нефтешламов // Экология и промышленность России. 2002. №5. С. 20-23.

3 Лагутенко М.А., Литвинова Т.А., Косулина Т.П. Направления совершенствования технологии термического обезвреживания нефтесодержащих отходов // Политематический 
сетевой электронный научный журнал Кубанского государственного аграрного университета (Научный журнал КубГАУ) [Электронный ресурс]. - Краснодар: КубГАУ, 2013. - №09(093). - IDA [article ID]: 0931309113. - Режим доступа: http://ej.kubagro.ru/2013/09/pdf/113.pdf

4 Лагутенко М.А., Литвинова Т.А., Косулина Т.П. Разработка способа обезвреживания нефтешламов и нефтегрунтов термическим методом с получением продуктов для промышленного строительства // Экологический вестник научных центров черноморского экономического сотрудничества. 2014. №1. С.52-58.

5 Бакастова Н. В. Решение проблем по переработке нефтешламов методом цетробежной сепарации // Нефтяное хозяйство. 2005. №3. С. 36-37.

6 Кусакин А.Л., Мкртычев А.А. Флюидизационная установка «SEPS-MK-IV» для переработки нефтешлама // Нефтяное хозяйство. 2004. №12. С. 128-131.

7 Логунова Ю.В., Гержберг Ю.М., Токарев В.В., Штриплинг Л.О. Исследование устойчивости органоминерального материала «Прекан» под воздействием природных факторов и оценка его влияния на окружающую среду // Защита окружающей среды в нефтегазовом комплексе. 2009. № 2. С. 30-33.

8 Рудник М.И., Кичигин О.В. Технология переработки и утилизации нефтяных отходов с применением оборудования «ИНСТЭБ» // Мир нефтепродуктов. 2004. №4. С. 33-35.

9 Маликова М.Ю., Сташок Ю.И. Новая технология утилизации промышленных отходов, содержащих нефть и нефтепродукты // Транспорт и хранение нефтепродуктов. 2005. №8. C.22-24.

10 Воробьева С.Ю., Шпинькова М.С., Мерициди И.А. Переработка нефтешламов, буровых шламов, нефтезагрязненных грунтов методом реагентного капсулирования // Территория Нефтегаз. 2011. № 2. С. 68-71.

11 Ларионов К.С., Меркулов В.В., Холкин Е.Г. Уточнение рецептуры обезвреживания нефтесодержащих отходов методом реагентного капсулирования // Омский научный вестник. 2015. № 144. С. 269-273.

12 Литвинова Т.А., Винникова Т.В., Косулина Т.П. Реагентный способ обезвреживания нефтешламов // Экология и промышленность России. 2009. №10. С. 40-43.

13 Косулина Т.П., Кононенко Е.А. Повышение экологической безопасности продукта утилизации нефтяных шламов // Политематический сетевой электронный научный журнал Кубанского государственного аграрного университета. 2012. №78. Режим доступа: http://ej.kubagro.ru/2012/04/pdf/64.pdf

14 Косулина Т.П., Цокур О.С., Литвинова Т.А. Использование обезвреживающей композиции для утилизации нефтешламов и отработанного сорбента ОДМ-2Ф // Экологический вестник научных центров Черноморского экономического сотрудничества. 2013. № 3. С. 77-84.

15 Мазлова Е.А., Мещеряков С.В., Климова Л.З. Реагентное разделение заводских нефтесодержащих шламов и осадков // Химия и технология топлив и масел. 2000. № 6. С. 46-47.

16 Ягафарова Г.Г., Ильина Е.Г., Гатауллина Э.М., Барахнина В.Б. Биотехнологический метод очистки нефтешлама // Транспорт и хранение нефтепродуктов. 2004. №9. С. 10-13.

17 Мингулов Ш.Г., Миникаев Ф.Н. Опыт природоохранной деятельности ООО НГДУ «Туймазанефть» в области биоразложения нефтешламов и улавливания легких фракций углеводородов // Экологическая и промышленная безопасность. 2004. №8. С. 40-41.

18 Хайрудинов И.Р., Тихонов А.А., Теляшев Э.Г., Магид А.Б. Комплексная схема утилизации жидких и твердых нефтесодержащих отходов. Тезисы докладов // Нефтегазопереработка и нефтехимия 2006: международная научно-практическая конференция. Уфа. 2006. С.238-240. 
19 Ягудин Н. Г. Вариант комплексного решения «шламовых» проблем на предприятиях нефтепереработки и нефтехимии // Защита окружающей среды в нефтегазовом комплексе. 2005. № 3. С.77-82.

20 Литвинова Т.А., Цокур О.С., Зубенко Ю.Ю., Косулина Т.П. Решение проблемы утилизации нефтесодержащих отходов с вовлечением их в ресурсооборот // Современные проблемы науки и образования. 2012. №6. http://www.scienceeducation.ru/106-7707.

21 Litvinova T.A., Kosulina T., Shadrina D., Chirkova S. Recycling of oil-slimes by chemical method // European Academy Of Natural History. - 2010. - №1. - C. 77

22 Шевцова Е.С., Литвинова Т.А. Анализ эффективности обезвреживания нефтесодержащих отходов реагентным методом // Актуальные проблемы науки и техники. Материалы VII Международной научно-практической конференции молодых ученых. Уфа: Редакционно-издательский центр УГНТУ, 2014. Т.2. С101-103.

23 Litvinova T.A., Kosulina T.P. Innovative resource saving technologies of oilcontaining waste utilization // The first international scientific conference "Science of the Future". Abstracts. http://p220conf.ru/abstracts/download/7-earth/112-t-litvinova

24 Косулина Т.П., Кононенко Е.А., Гамарский Д.М., Чернушина А.Н. Способ утилизации нефтесодержащих отходов: пат. 2354670 Рос. Федерация. № 2008102433/04, заявл. 22.01.2008; опубл. 10.05.2009. Бюл. 13.6 с.

25 Косулина Т.П., Кононенко Е.А. Способ утилизации нефтесодержащих отходов: пат. 2359982 Рос. Федерация. №2008102432/04; заявл. 22.01.2008; опубл. 27.06.2009. Бюл. 18. 5 с.

26 Косулина Т.П., Литвинова (Солнцева) Т.А. Способ обезвреживания нефтесодержащего шлама: Пат. 2395466 Рос. Федерация. №2008147569; заявл. 02.12.2008; опубл. 27.07.2010. Бюл. №21. 7 с.

27 Литвинова (Солнцева) Т.А., Косулина Т.П. Линия по обезвреживанию нефтесодержащего шлама: пат. 82208 Рос. Федерация, заявл. 29.12.08, опубл. 20.04.2009. Бюл. №11. 4 с.

28 Литвинова Т.А., Косулина Т.П., Щадрина Д.С., Чиркова С.С. Линия по производству органоминеральной добавки: пат. 93791. Рос. Федерация, заявл. 15.01.2010. опубл. 10.05.2010. Бюл. №13. 4 c.

29 Косулина Т.П., Кононенко Е.А., Рогожева И.С. Технологическая линия комплексного обезвреживания застаревших нефтяных шламов: пат. 92009. Рос. Федерация. №2009146853; заявл. 16.12.2009; опубл. 10.03.2010. Бюл. №7. 4 с.

30 Литвинова Т.А, Косулина Т.П. Способ получения органоминеральной добавки к строительным материалам: пат. 2548441 Рос. Федерация. № 2013155369/20(086401); заявл. 12.12.2013, опубл. 20.04.2015. Бюл. №11. 5 с.

31 Литвинова Т.А., Цокур О.С., Косулина Т.П. О выборе наилучших доступных технологий утилизации отходов нефтегазовой отрасли // Современные проблемы науки и образования 2012. №6. (приложение "Технические науки"). С. 53.

32 Косулина Т.П., Литвинова Т.А., Цокур О.С Применение наилучших доступных технологий для утилизации промышленных отходов // Сборник докладов IV Международной научной экологической конференции на тему: "Проблемы рекультивации отходов быта, промышленного и сельскохозяйственного производства". Краснодар: Кубанский госагроуниверситет, 2015. - Ч. 1. - С.728-732.

33 Литвинова Т.А. Инновационный подход на основе принципов НДТ к разработке технологий утилизации нефтесодержащих отходов // Политематический сетевой электронный научный журнал Кубанского государственного аграрного университета (Научный журнал КубГАУ) [Электронный ресурс]. - Краснодар: КубГАУ, 2016. - №1(115). - IDA [article ID]: 1151601019. - Режим доступа:http://ej.kubagro.ru/2016/01/pdf/19.pdf, 0,750 у.п.л. 


\section{References}

1 Chernjahovskij Je. R., Shkidchenko A. N., Jumatova O. A., Chushkina Z. Ju. Primenenie razlichnyh tehnologij pri likvidacii posledstvij avarijnyh razlivov nefti, nefteproduktov i produktov pererabotki neftesoderzhashhih othodov // Zashhita naselenija i territorii ot chrezvychajnyh situacij. 2003. № 2. S.12-13.

2 Dudyshev V.D. Utilizacija nefteshlamov // Jekologija i promyshlennost' Rossii. 2002.№5.S.20-23.

3 Lagutenko M.A., Litvinova T.A., Kosulina T.P. Napravlenija sovershenstvovanija tehnologii termicheskogo obezvrezhivanija neftesoderzhashhih othodov // Politematicheskij setevoj jelektronnyj nauchnyj zhurnal Kubanskogo gosudarstvennogo agrarnogo universiteta (Nauchnyj zhurnal KubGAU) [Jelektronnyj resurs]. - Krasnodar: KubGAU, 2013. - №09(093). - IDA [article ID]: 0931309113. - Rezhim dostupa: http://ej.kubagro.ru/2013/09/pdf/113.pdf

4 Lagutenko M.A., Litvinova T.A., Kosulina T.P. Razrabotka sposoba obezvrezhivanija nefteshlamov i neftegruntov termicheskim metodom $\mathrm{s}$ polucheniem produktov dlja promyshlennogo stroitel'stva // Jekologicheskij vestnik nauchnyh centrov chernomorskogo jekonomicheskogo sotrudnichestva. 2014. №1. S.52-58.

5 Bakastova N. V. Reshenie problem po pererabotke nefteshlamov metodom cetrobezhnoj separacii // Neftjanoe hozjajstvo. 2005. №3. S. 36-37.

6 Kusakin A.L., Mkrtychev A.A. Fljuidizacionnaja ustanovka «SEPS-MK-IV» dlja pererabotki nefteshlama // Neftjanoe hozjajstvo. 2004. №12. S. 128-131.

7 Logunova Ju.V., Gerzhberg Ju.M., Tokarev V.V., Shtripling L.O. Issledovanie ustojchivosti organomineral'nogo materiala «Prekan» pod vozdejstviem prirodnyh faktorov i ocenka ego vlijanija na okruzhajushhuju sredu // Zashhita okruzhajushhej sredy v neftegazovom komplekse. 2009. № 2. S. 30-33.

8 Rudnik M.I., Kichigin O.V. Tehnologija pererabotki i utilizacii neftjanyh othodov s primeneniem oborudovanija «INSTJeB» // Mir nefteproduktov. 2004. №4. S. 33-35.

9 Malikova M.Ju., Stashok Ju.I. Novaja tehnologija utilizacii promyshlennyh othodov, soderzhashhih neft' i nefteprodukty // Transport i hranenie nefteproduktov. 2005. №8. S.22-24.

10 Vorob'eva S.Ju., Shpin'kova M.S., Mericidi I.A. Pererabotka nefteshlamov, burovyh shlamov, neftezagrjaznennyh gruntov metodom reagentnogo kapsulirovanija // Territorija Neftegaz. 2011. № 2. S. 68-71.

11 Larionov K.S., Merkulov V.V., Holkin E.G. Utochnenie receptury obezvrezhivanija neftesoderzhashhih othodov metodom reagentnogo kapsulirovanija // Omskij nauchnyj vestnik. 2015. № 144. S. 269-273.

12 Litvinova T.A., Vinnikova T.V., Kosulina T.P. Reagentnyj sposob obezvrezhivanija nefteshlamov // Jekologija i promyshlennost' Rossii. 2009. №10. S. 40-43.

13 Kosulina T.P., Kononenko E.A. Povyshenie jekologicheskoj bezopasnosti produkta utilizacii neftjanyh shlamov // Politematicheskij setevoj jelektronnyj nauchnyj zhurnal Kubanskogo gosudarstvennogo agrarnogo universiteta. 2012. №78. Rezhim dostupa: http://ej.kubagro.ru/2012/04/pdf/64.pdf

14 Kosulina T.P., Cokur O.S., Litvinova T.A. Ispol'zovanie obezvrezhivajushhej kompozicii dlja utilizacii nefteshlamov i otrabotannogo sorbenta ODM-2F // Jekologicheskij vestnik nauchnyh centrov Chernomorskogo jekonomicheskogo sotrudnichestva. 2013. № 3. S. 77-84.

15 Mazlova E.A., Meshherjakov S.V., Klimova L.Z. Reagentnoe razdelenie zavodskih neftesoderzhashhih shlamov i osadkov // Himija i tehnologija topliv i masel. 2000. № 6. S. 46-47.

16 Jagafarova G.G., Il'ina E.G., Gataullina Je.M., Barahnina V.B. Biotehnologicheskij metod ochistki nefteshlama // Transport i hranenie nefteproduktov. 2004. №9. S. 10-13.

17 Mingulov Sh.G., Minikaev F.N. Opyt prirodoohrannoj dejatel'nosti OOO NGDU «Tujmazaneft'» v oblasti biorazlozhenija nefteshlamov i ulavlivanija legkih frakcij uglevodorodov // Jekologicheskaja i promyshlennaja bezopasnost'. 2004. №8. S. 40-41. 
18 Hajrudinov I.R., Tihonov A.A., Teljashev Je.G., Magid A.B. Kompleksnaja shema utilizacii zhidkih i tverdyh neftesoderzhashhih othodov. Tezisy dokladov // Neftegazopererabotka i neftehimija 2006: mezhdunarodnaja nauchno-prakticheskaja konferencija. Ufa. 2006. S.238-240.

19 Jagudin N. G. Variant kompleksnogo reshenija «shlamovyh» problem na predprijatijah neftepererabotki i neftehimii // Zashhita okruzhajushhej sredy v neftegazovom komplekse. 2005. № 3. S.77-82.

20 Litvinova T.A., Cokur O.S., Zubenko Ju.Ju., Kosulina T.P. Reshenie problemy utilizacii neftesoderzhashhih othodov s vovlecheniem ih v resursooborot // Sovremennye problemy nauki i obrazovanija. 2012. №6. http://www.science-education.ru/106-7707.

21 Litvinova T.A., Kosulina T., Shadrina D., Chirkova S. Recycling of oil-slimes by chemical method // European Academy Of Natural History. - 2010. - №1. - S. 77

22 Shevcova E.S., Litvinova T.A. Analiz jeffektivnosti obezvrezhivanija neftesoderzhashhih othodov reagentnym metodom // Aktual'nye problemy nauki i tehniki. Materialy VII Mezhdunarodnoj nauchno-prakticheskoj konferencii molodyh uchenyh. Ufa: Redakcionno-izdatel'skij centr UGNTU, 2014. T.2. S101-103.

23 Litvinova T.A., Kosulina T.P. Innovative resource saving technologies of oilcontaining waste utilization // The first international scientific conference "Science of the Future". Abstracts. http://p220conf.ru/abstracts/download/7-earth/112-t-litvinova

24 Kosulina T.P., Kononenko E.A., Gamarskij D.M., Chernushina A.N. Sposob utilizacii neftesoderzhashhih othodov: pat. 2354670 Ros. Federacija. № 2008102433/04, zajavl. 22.01.2008; opubl. 10.05.2009. Bjul. 13. $6 \mathrm{~s}$.

25 Kosulina T.P., Kononenko E.A. Sposob utilizacii neftesoderzhashhih othodov: pat. 2359982 Ros. Federacija. №2008102432/04; zajavl. 22.01.2008; opubl. 27.06.2009. Bjul. 18. 5 s.

26 Kosulina T.P., Litvinova (Solnceva) T.A. Sposob obezvrezhivanija neftesoderzhashhego shlama: Pat. 2395466 Ros. Federacija. №2008147569; zajavl. 02.12.2008; opubl. 27.07.2010. Bjul. №21. 7 s.

27 Litvinova (Solnceva) T.A., Kosulina T.P. Linija po obezvrezhivaniju neftesoderzhashhego shlama: pat. 82208 Ros. Federacija, zajavl. 29.12.08, opubl. 20.04.2009. Bjul. №11. 4 s.

28 Litvinova T.A., Kosulina T.P., Shhadrina D.S., Chirkova S.S. Linija po proizvodstvu organomineral'noj dobavki: pat. 93791. Ros. Federacija, zajavl. 15.01.2010. opubl. 10.05.2010. Bjul. №13. 4 s.

29 Kosulina T.P., Kononenko E.A., Rogozheva I.S. Tehnologicheskaja linija kompleksnogo obezvrezhivanija zastarevshih neftjanyh shlamov: pat. 92009. Ros. Federacija. №2009146853; zajavl. 16.12.2009; opubl. 10.03.2010. Bjul. №7. 4 s.

30 Litvinova T.A, Kosulina T.P. Sposob poluchenija organomineral'noj dobavki k stroitel'nym materialam: pat. 2548441 Ros. Federacija. № 2013155369/20(086401); zajavl. 12.12.2013, opubl. 20.04.2015. Bjul. №11. $5 \mathrm{~s}$.

31 Litvinova T.A., Cokur O.S., Kosulina T.P. O vybore nailuchshih dostupnyh tehnologij utilizacii othodov neftegazovoj otrasli // Sovremennye problemy nauki i obrazovanija 2012. №6. (prilozhenie "Tehnicheskie nauki"). C. 53.

32 Kosulina T.P., Litvinova T.A., Cokur O.S Primenenie nailuchshih dostupnyh tehnologij dlja utilizacii promyshlennyh othodov // Sbornik dokladov IV Mezhdunarodnoj nauchnoj jekologicheskoj konferencii na temu: "Problemy rekul'tivacii othodov byta, promyshlennogo i sel'skohozjajstvennogo proizvodstva". Krasnodar: Kubanskij gosagrouniversitet, 2015. - Ch. 1. - S.728-732.

33 Litvinova T.A. Innovacionnyj podhod na osnove principov NDT $\mathrm{k}$ razrabotke tehnologij utilizacii neftesoderzhashhih othodov // Politematicheskij setevoj jelektronnyj nauchnyj zhurnal Kubanskogo gosudarstvennogo agrarnogo universiteta (Nauchnyj zhurnal KubGAU) [Jelektronnyj resurs]. - Krasnodar: KubGAU, 2016. - №01(115). - IDA [article ID]: 1151601019. - Rezhim dostupa:http://ej.kubagro.ru/2016/01/pdf/19.pdf, 0,750 u.p.l. 